\title{
CROSS-CULTURAL ADAPTATION AND VALIDITY OF THE "EDMONTON FRAIL SCALE - EFS" IN A BRAZILIAN ELDERLY SAMPLE ${ }^{1}$
}

\author{
Suzele Cristina Coelho Fabrício-Wehbe ${ }^{2}$ \\ Fábio Veiga Schiaveto ${ }^{3}$ \\ Thaís Ramos Pereira Vendrusculo ${ }^{4}$ \\ Vanderlei José Haas ${ }^{5}$ \\ Rosana Aparecida Spadoti Dantas ${ }^{6}$ \\ Rosalina Aparecida Partezani Rodrigues ${ }^{7}$
}

Fabrício-Wehbe SCC, Schiaveto FV, Vendrusculo TRP, Haas VJ, Dantas RAS, Rodrigues RAP. Cross-cultural adaptation and validity of the "Edmonton Frail Scale - EFS" in a brazilian elderly sample. Rev Latino-am Enfermagem 2009 novembro-dezembro; 17(6):1043-9.

This study aimed to assess the cross-cultural adaptation of the Edmonton Frail Scale (EFS) and its validity in a Brazilian elderly sample. Translation and back-translation were performed, as well as discussion with professionals and elderly for conceptual equivalence, semantic validation and pre-test of the scale. The scale was applied to 137 elderly aged 65 years or older who lived in the community. In the know-groups validation of the frailty diagnosis between gender, age and cognitive deficit, elder elderly, female and with a cognitive deficit scored higher on the frailty diagnosis. A negative convergent correlation was found between the EFS and the Functional Independence Measure (FIM) $(-0.53, p<0.01)$ and the total score of the Mini-Mental State Examination (MMSE) $(-0.60, p<0.01)$. The watch test presented high sensitivity and low specificity levels. The Portuguese version of the EFS was considered valid in the study sample.

DESCRIPTORS: frail elderly; nursing methodology research; cross-cultural comparison; validation studies

\section{ADAPTACIÓN CULTURAL Y VALIDEZ DE LA EDMONTON FRAIL SCALE - EFS EN UNA MUESTRA DE ANCIANOS BRASILEÑOS}

El objetivo de este estudio fue evaluar la adaptación cultural de la Edmonton Frail Scale (EFS) y su validez en una muestra de ancianos brasileños. Fueron realizadas las etapas de traducción y retrotraducción, discusión con profesionales y ancianos para equivalencia conceptual, validación semántica y prueba piloto de la escala. El instrumento fue aplicado en 137 ancianos, con 65 años o más de edad, que vivían en la comunidad. En la validación de grupos conocidos, del diagnóstico de fragilidad entre sexo, edad y déficit cognitivo, los ancianos con edad más avanzada, sexo femenino y con déficit cognitivo tuvieron mayor puntuación en el diagnóstico de fragilidad. Hubo una correlación convergente negativa de la EFS con la Medida de Independencia Funcional (MIF) $(-0,53, p<0,01)$ y el puntaje bruto del Mini-Examen del Estado Mental (MEEM) $(-0,60, p<0,01)$. La prueba del reloj presentó alta sensibilidad y baja especificidad. La versión para la lengua portuguesa de la EFS fue considerada válida en la muestra estudiada.

DESCRIPTORES: anciano frágil; investigación metodológica en enfermería; comparación transcultural; estudios de validación

\section{ADAPTAÇÃO CULTURAL E VALIDADE DA EDMONTON FRAIL SCALE - EFS EM UMA AMOSTRA DE IDOSOS BRASILEIROS}

O objetivo deste estudo foi avaliar a adaptação cultural da Edmonton Frail Scale (EFS) e sua validade em uma amostra de idosos brasileiros. Foram realizadas as etapas de tradução e retrotradução, discussão com profissionais e idosos para equivalência conceitual, validação semântica e pré-teste da escala. O instrumento foi aplicado em 137 idosos, com 65 anos ou mais de idade, que viviam na comunidade. Na validação de grupos conhecidos, do diagnóstico de fragilidade entre sexo, idade e déficit cognitivo, idosos com idade mais avançada, sexo feminino e com déficit cognitivo tiveram maior pontuação no diagnóstico de fragilidade. Houve correlação convergente negativa da EFS com a Medida de Independência Funcional (MIF) $(-0,53, p<0,01)$ e o escore bruto do Mini-Exame do Estado Mental (MEEM) $(-0,60, p<0,01)$. O teste do relógio apresentou alta sensibilidade e baixa especificidade. A versão para língua portuguesa da EFS foi considerada válida na amostra estudada.

DESCRITORES: idoso fragilizado; pesquisa metodológica em enfermagem; comparação transcultural; estudos de validação

${ }^{1}$ Paper extracted from Doctoral Dissertation. ${ }^{2} \mathrm{RN}$, Doctoral Student, Programa Interunidades de Doutoramento em Enfermagem da Escola de Enfermagem e Escola de Enfermagem de Ribeirão Preto, Universidade de São Paulo, Brazil. Faculty, Centro Universitário Barão de Mauá, Ribeirão Preto, SP, Brazil. E-mail: suzelecris@ig.com.br. ${ }^{3}$ RN, M.Sc. in Nursing, e-mail : schiaveto@yahoo.com.br. ${ }^{4} \mathrm{RN}$, CNPq grantholder - technical support, e-mail: thaisvendruscolo@yahoo.com.br. ${ }^{5}$ Ph.D., Postdoctoral Student, - CNPq. e-mail: vjhaas@uol.com.br. ${ }^{6}$ Ph.D. in Sciences, Colaborating Professor, Escola de Enfermagem de Ribeirão Preto, Universidade de São Paulo, WHO Collaborating Centre for Nursing Research Development, Brazil, e-mail:haas@eerp.usp.br. ${ }^{7}$ Full Professor, Escola de Enfermagem de Ribeirão Preto, Universidade de São Paulo, WHO Collaborating Centre for Nursing Research Development, Brazil, e-mail: rosalina@eerp.usp.br. 


\section{INTRODUCTION}

Frailty among elderly people has emerged as an important concept in gerontology and geriatric. It is mentioned as a significant risk factor for falls, disability, hospitalization and death in this population $^{(1)}$. The theme has received little attention from Brazilian and international researchers, however, and no scientific consensus has been reached yet on its definition and indicators.

Frailty can manifest itself in people of all ages, including the elderly. It should not be considered a synonym of old age, however. Nowadays, it has been strongly considered a multidimensional syndrome, involving different factors: biological, physical, cognitive, social, economic and environmental ${ }^{(2-3)}$. It is a type of syndrome that can be avoided when identified at an early stage, or at least delayed through interventions based on its indicators ${ }^{(4)}$.

Two main branches of frailty studies exist in international literature, represented by two research groups: one in the United States and another in Canada. The group established in Canada, the Canadian Initiative on Frailty and Aging (CIF-A), collaborates with some European countries, Israel and Japan. It started in 2002 and specialized research has been performed ${ }^{(5)}$. Canadian participants in this group have studied a clinical proposal to detect frailty in elderly people, called the Edmonton Frail Scale $(E F S)^{(3)}$. It has been validated and is considered reliable for routine use, even by non-specialists in geriatrics and gerontology. Its authors believe it is a more complete clinical proposal to detect frailty in elderly people, which is easy to handle and apply. They also believe it is a broader scale as, in their opinion, cognition, mood and social support aspects can also be considered indicators of frailty in the elderly ${ }^{(3)}$.

During multidimensional assessment of the elderly, health professionals can detect many risk factors for frailty and act to prevent the emergence and/or worsening of this state. This demands objective instruments (scales) that are easy and readily applicable, have been validated and can more objectively appoint the frailty indicators that need to be assessed in the elderly population. Hence, this research aimed to perform the cultural adaptation of the Edmonton Frail Scale (EFS) and find evidence for the validity of the adapted version in a sample of Brazilian elderly. The use of this adapted scale will permit researchers, professionals and public health policy makers to identify frailty among Brazilian elderly, developing more adequate and specific interventions for this population.

\section{CASES AND METHODS}

The EFS is a scale to assess frailty in the elderly. It was elaborated by Rolfson and collaborators at the University of Alberta, Edmonton, Canada in 2006. The scale evaluates nine domains: cognition, general health status, functional independence, social support, medication use, nutrition, mood, continence and functional performance, investigated through 11 items. The maximum score is 17 , representing the highest level of frailty. Frailty analysis scores are: 04, no frailty; 5-6, apparently vulnerable; 7-8, mild frailty; $9-10$, moderate frailty; 11 or more, severe frailty.

The cultural adaptation was performed in line with the theoretical reference framewok by Guillemin, Bombardier and Beaton ${ }^{(6)}$. The order of phases was modified as proposed by $\operatorname{Ferrer}^{(7)}$, modifications that have been used in Brazilian research ${ }^{(8-10)}$ : translation fo the scale to Portuguese; achievement of the first consensus version in Portuguese; assessment by an expert committee; back translation; achievement of consensus version in English and comparison with the original version; semantic assessment of the instrument and pretest of the Portuguese version.

Initially, two Brazilian nationals with large knowledge of English translated the original EFS to Portuguese. The translators assessed and discussed differences between both translations together with the researcher and her advisor, choosing the most appropriate option that would not modify the meaning expressed in the original instrument. The Portuguese consensus version was submitted to a committee of seven experts, composed according to the following criteria: knowledge on the research theme (aging and frailty), mastery of Portuguese and English and knowledge of the cross-cultural adaptation methodology. Before participating in this committee, each member signed a free and informed consent term, agreeing with participation in the research and with the use of the discussed data. At that moment, the final version in Portuguese was created.

After the translation to Portuguese, the back translation was started. For this purposes, two 
American translators who have lived in Brazil for several years received the consensus version in Portuguese. They were not informed about the study objectives and did not know the original version of the scale. After the translations were done, two backtranslated versions were obtained. To solve some differences between these, a meeting was held between the researcher, her advisor and the two translators. At that moment, the study goals and the two versions (original and back translation) were presented for analysis, resulting in a consensus version in Portuguese and in English.

Semantic analysis was performed by applying the scale to six elderly living in the community, with similar characteristics and age ranges but different genders (three women and three men), randomly selected, complying with strict ethical guidelines. In this phase, the version applied to the elderly was not changed, as both the elderly and/or their caregivers considered they could understand it well and suggested no modifications. Later, for the pretest, the scale was applied to 40 elderly living in the community. These were selected in accordance with the criterion established for this research and specified further ahead, but were not included in the validity assessment of the scale. Like in semantic analysis, no scale items needed alterations and the interviewees understood the scale well, resulting in the final translated version. After performing the pretest and determining the final version of the scale, it was applied to a sample of elderly for validity analysis. This research, which is part of the project "Living and health conditions of elderly in Ribeirão Preto, São Paulo" was carried out in the urban area of Ribeirão Preto, São Paulo State, involving elderly people over 65 years of age who lived in the community. For this project, a probabilistic double-stage sampling process was used. In the first stage, the census sector was considered as the Primary Sampling Unit (PSU), randomly selecting 30 census sectors, with probability proportional to the number of residences, among the 600 sectors in the city. The second stage was to visit a fixed number of residences (110) in each sector, with a view to guaranteeing self-weighted sampling, randomly selecting the streets and blocks where this search process was started. As a form of prevention in case of refusals or no answers, 993 people were randomly selected. This figure resulted from a correction for a response rate of $80 \%$.
Data were collected between September 2007 and June 2008. The researchers interviewed 515 elderly but, for the psychometric analysis of the EFS, a subsample of 137 elderly people was selected, using simple random sampling (SRS). Two possibilities were considered to calculate the sample size: 1) construct validity - to select the subsample, the categorized fragility diagnosis was correlated with the FIM, using Spearman's correlation coefficient as an indicator, $\alpha=0.01$ and $\beta=0.10, H_{a}=0.90$ and $H_{0}=0.0$, with statistical power corresponding to 0.90 ; this resulted in a sample need of 94 elderly; 2) reliability - to check reliability, the global EFS score was used, with the intraclass (ICC) and interrater correlation coefficient as an indicator, $\alpha=0.01$ and $\beta=0.1$ and statistical power of $0.90, \mathrm{H}_{\mathrm{a}}$ : ICC $=0.90$ and $\mathrm{H}_{0}$ : ICC $=0.8$, and two evaluators. The size of this sample was determined at 109 elderly. Considering $20 \%$ of losses, the sample need of 137 elderly was found for reliability tests. In the end, the sampling criterion of reliability was used, as that was the largest sample size demanded in this research. Statistical Package for the Social Science (SPSS) software, version 15.0, was used for the random selection of this sample, based on a random number generator.

Data were collected by interviewers whom the project advisor and researcher had trained, wearing a uniform and properly identified with a badge. They interviewed the elderly at their homes, using an instrument with the following information: sociodemographic data, cognitive assessment (MMSE) - functional independence (FIM) and frailty (Edmonton Frail Scale - EFS). Before the start of the interviews, the free and informed consent term was read to the elderly and/or caregiver to obtain their signature and authorization.

Data were inserted in EXCEL, and a database was elaborated, using the double-entry (typing) validation technique. After typing and verifying data consistency, data were imported and analyzed in SPSS 15.0

To analyze the construct validity of the EFS, Spearman's non-parametric rank correlation coefficient was calculated, between the frailty diagnosis and the gross MMSE score and the FIM diagnosis. Known-groups validation was also carried out, using Mann-Whitney's non-parametric test of the frailty diagnosis between gender, age and cognitive deficit. In this study, the sensitivity and 
specificity of the clock test (cognitive dimension) of the EFS were calculated as a criterion validity measure for a specific item.

Before the start of interviews with the elderly, this research project was evaluated and approved by the Research Ethics Committee at the University of São Paulo at Ribeirão Preto College of Nursing.

\section{RESULTS}

During the analysis of the EFS' translation to Portuguese and the consensus by the expert committee, face and content validation could be verified, that is, the scale measures what it intends to measure (face validation) and its items are relevant for the construct under analysis (content validation).

Most participants, i.e. 102 (74.5\%) were women, widowed $(58-42.3 \%)$, with a mean age of 75.33 years (standard deviation 8.01, minimum age 65 and maximum 100 years), and mean formal education between one and four years of study (75 $54.8 \%)$.

In known-groups validation and comparative analysis of the frailty diagnosis between gender, age and cognitive deficit, three missing data or no answers were observed. This corresponded to the number of elderly who, because they did not speak or suffered from advanced dementia, did not answer the questionnaires, according to Table 1.

Table 1 - Results of association tests between gender, age, cognitive deficit and frailty diagnosis variables. Ribeirão Preto, 2007-2008

\begin{tabular}{|c|c|c|c|c|c|c|c|c|c|c|c|c|}
\hline \multirow{3}{*}{ Variables } & \multicolumn{12}{|c|}{ Frailty diagnosis } \\
\hline & \multicolumn{2}{|c|}{ No frailty } & \multicolumn{2}{|c|}{$\begin{array}{l}\text { Apparently } \\
\text { vulnerable }\end{array}$} & \multicolumn{2}{|c|}{ Mild frailty } & \multicolumn{2}{|c|}{ Moderate frailty } & \multicolumn{2}{|c|}{ Severe frailty } & \multicolumn{2}{|c|}{ Total } \\
\hline & $\mathbf{N}$ & $\%$ & $\mathbf{N}$ & $\%$ & $\mathbf{N}$ & $\%$ & $\mathbf{N}$ & $\%$ & $\mathbf{N}$ & $\%$ & $\mathbf{N}$ & $\%$ \\
\hline \multicolumn{13}{|l|}{ Gender } \\
\hline Male & 21 & 60 & 7 & 20 & 5 & 14.3 & 2 & 5.7 & 0 & 0 & 35 & 100 \\
\hline Female & 45 & 44.1 & 21 & 20.6 & 17 & 16.7 & 12 & 11.8 & 7 & 6.9 & 102 & 100 \\
\hline Total & 66 & 49.3 & 28 & 20.9 & 22 & 16.4 & 14 & 9 & 7 & 4.5 & 137 & 100 \\
\hline \multicolumn{13}{|l|}{ Cognitive deficit } \\
\hline Yes & 5 & 21.7 & 2 & 8.7 & 6 & 26.1 & 6 & 26.1 & 4 & 17.4 & 23 & 100 \\
\hline No & 61 & 55 & 26 & 23.4 & 16 & 14.4 & 6 & 5.4 & 2 & 1.8 & 111 & 100 \\
\hline Total & 66 & 49.3 & 28 & 20.9 & 22 & 16.4 & 12 & 9 & 6 & 4.5 & 134 & 100 \\
\hline \multicolumn{13}{|l|}{ Age range } \\
\hline 65-79 & 53 & 57.6 & 19 & 20.7 & 13 & 14.1 & 3 & 3.3 & 4 & 4.3 & 92 & 100 \\
\hline $80+$ & 13 & 28.9 & 9 & 20 & 9 & 20 & 11 & 24.4 & 3 & 6.7 & 45 & 100 \\
\hline Total & 66 & 48.2 & 28 & 20.4 & 22 & 16.1 & 14 & 10.2 & 7 & 5.1 & 137 & 100 \\
\hline
\end{tabular}

In the known-groups validation, elder elderly patients, female and with a cognitive deficit scored higher on the frailty diagnosis, being classified as more fragile. All comparisons were statistically significant, with $p<0.001$ on the MannWhitney tests.
For convergent construct validity, the diagnoses obtained on EFS were compared with the FIM and the MMSE.

Results for the elderly people's distribution according to functional dependence (FIM) and frailty diagnosis (EFS) are displayed in Table 2.

Table 2 - Results of association tests between functional performance and frailty diagnoses. Ribeirão Preto, 2007-2008

\begin{tabular}{|c|c|c|c|c|c|c|c|c|c|c|c|c|}
\hline \multirow{3}{*}{ Functional performan } & \multicolumn{12}{|c|}{ Frailty diagnosis } \\
\hline & \multicolumn{2}{|c|}{ No frailty } & \multicolumn{2}{|c|}{$\begin{array}{l}\text { Apparently } \\
\text { vulnerable }\end{array}$} & \multicolumn{2}{|c|}{ Mild frailty } & \multicolumn{2}{|c|}{ Moderate frailty } & \multicolumn{2}{|c|}{ Severe frailty } & \multicolumn{2}{|c|}{ Total } \\
\hline & $\mathbf{N}$ & $\%$ & $\mathbf{N}$ & $\%$ & $\mathbf{N}$ & $\%$ & $\mathbf{N}$ & $\%$ & $\mathbf{N}$ & $\%$ & $\mathbf{N}$ & $\%$ \\
\hline Complete dependence & 0 & 0 & 0 & 0 & 0 & 0 & 0 & 0 & 1 & 100 & 1 & 100 \\
\hline Moderate dependence & 0 & 0 & 1 & 25 & 0 & 0 & 3 & 75 & 0 & 0 & 4 & 100 \\
\hline Minimal dependence & 0 & 0 & 1 & 7.1 & 4 & 28.6 & 5 & 35.7 & 4 & 28.6 & 14 & 100 \\
\hline Complete independence & 66 & 55.9 & 26 & 22 & 18 & 15.3 & 6 & 5.1 & 2 & 1.7 & 118 & 100 \\
\hline Total & 66 & 48.2 & 28 & 20.4 & 22 & 16.1 & 14 & 10.2 & 7 & 5.1 & 137 & 100 \\
\hline
\end{tabular}


The convergence between both constructs was quantified through Spearman's correlation coefficient, illustrated in Table 3.

Table 3 - Spearman's correlation coefficient of FIM with EFS frailty diagnosis. Ribeirão Preto, 2007-2008

\begin{tabular}{lcccc}
\hline $\begin{array}{c}\text { Spearman's } \\
\text { correlation } \\
\text { coefficient }\end{array}$ & Global FIM & Motor FIM & $\begin{array}{c}\text { Cognitive } \\
\text { FIM }\end{array}$ & $\begin{array}{c}\text { Frailty } \\
\text { diagnosis }\end{array}$ \\
\hline Global FIM & 1.000 & $0.932^{* *}$ & $0.851^{* *}$ & $-0.703^{* *}$ \\
Motor FIM & $0.932^{* *}$ & 1.000 & $0.646^{* *}$ & $-0.714^{* *}$ \\
Cognitive FIM & $0.851^{* *}$ & $0.646^{* *}$ & 1.000 & $-0.575^{\star *}$ \\
Frailty diagnosis & $-0.703^{* *}$ & $-0.714^{* *}$ & $-0.575^{* *}$ & 1.000 \\
\hline $\mathrm{n}=137 \mathrm{p}<0.01$ & & & &
\end{tabular}

A negative correlation was found between the EFS and FIM scores, as both are inversely ordered. According to a classification recommended by literature ${ }^{(11)}$, the correlation between the frailty diagnosis and the global and motor FIM scores is moderate and negative, whereas a weak and negative correlation was found with cognitive FIM. All correlations were statistically significant $(p<0.01)$.

The negative and moderate ${ }^{(11)}$ correlation was maintained when analyzing the correlation between gross functional dependence and frailty scores, using Spearman's correlation coefficient, with statistical significance $(-0.53, \mathrm{p}<0.01)$.

Table 4 - Results of association tests between FIM and functional independence in EFS. Ribeirão Preto, 2007-2008

\begin{tabular}{|c|c|c|c|c|c|c|c|c|}
\hline \multirow{3}{*}{$\begin{array}{c}\text { Functional } \\
\text { independence }\end{array}$} & \multicolumn{8}{|c|}{ How many activities do you need help for } \\
\hline & \multicolumn{2}{|c|}{0 to 1} & \multicolumn{2}{|c|}{2 to 4} & \multicolumn{2}{|c|}{5 to 8} & \multicolumn{2}{|c|}{ Total } \\
\hline & $\mathbf{N}$ & $\%$ & $\mathbf{N}$ & $\%$ & $\mathbf{N}$ & $\%$ & $\mathbf{N}$ & $\%$ \\
\hline $\begin{array}{l}\text { Complete } \\
\text { dependence }\end{array}$ & 0 & 0 & 0 & 0 & 1 & 100 & 1 & 100 \\
\hline $\begin{array}{l}\text { Moderate } \\
\text { dependence }\end{array}$ & 1 & 25 & 0 & 0 & 3 & 75 & 4 & 100 \\
\hline $\begin{array}{l}\text { Minimal } \\
\text { dependence }\end{array}$ & 0 & 0 & 1 & 7.1 & 13 & 92.9 & 14 & 100 \\
\hline Independence & 88 & 74.6 & 17 & 14.4 & 13 & 11 & 118 & 100 \\
\hline Total & 89 & 65 & 18 & 13.1 & 30 & 21.9 & 137 & 100 \\
\hline
\end{tabular}

Applying Spearman's correlation coefficient, a negative correlation was found between functional independence on the EFS and FIM scores ( -0.57 , $\mathrm{p}<0.01)$. Results found when correlating the EFS with the gross MMSE score indicated a negative and weak correlation between the scales $(-0.607)$. In this case, once again, adequate negative convergent validity predominant, and all correlations were statistically significant $(p<0.01)$.

In this study, the sensitivity and specificity of the EFS clock test (cognitive dimension) were also calculated as a measure of criterion validity for a specific item. Sensitivity corresponded to $82.6 \%$ and specificity $36.9 \%$.

\section{DISCUSSION}

Analyzing whether the existence or not of a cognitive deficit was correlated with the frailty diagnosis, it was verified that most elderly people without a cognitive deficit are considered as 'no frailty'. Hence, it can be considered that elderly patients with severe frailty have a cognitive deficit. Chronic diseases causing cognitive and mental disability are more strongly associated with frailty in the elderly, which is considered a syndrome that, among other causes, can be provoked by organic system deficiency, including the cognitive system $^{(12)}$.

As to gender, women were considered more fragile than men. This fact needs further study, as the sample consists of women who are older than the men (Mann-Whitney test, discussed above, $p=0.044$ ). However, frailty could be a characteristic of female elderly. In a research by Cardiovascular Health Study, prevalence of frailty in the elderly population was identified at $6.9 \%$, and associations were found with some variables, including the female gender ${ }^{(13)}$. Many studies on falls from own height among elderly patients indicate that falls are more frequent among women. For some authors, the cause for these higher frequency levels is related to the fact that women are older and more fragile than men ${ }^{(14-15)}$. Table 1 shows that most elderly diagnosed as "no frailty" are between 65 and 79 years of age. According to some authors, frailty can be a characteristic of people aged 80 years or older ${ }^{(16)}$.

During the validation of the original scale, the authors $^{(3)}$ used Pearson's coefficient for analysis, with a significant correlation between EFS and age $(r=0.27$ and $p=0.015)$ and number of drugs $(r=0.34$ and $p<0.001)$, but not in relation to gender $(r=0.05$ and $p=0.647)$. 
Results for the correlation between EFS and FIM scores demonstrated a negative correlation, as they are inversely ordered, that is, higher FIM scores indicate lower EFS score, inversely correlated.

The analysis of the correlation between frailty diagnosis and FIM diagnosis and between frailty diagnosis and gross MMSE score showed a negative and moderate correlation for both ${ }^{(11)}$. The researchers' initial intent was to verify the possibility of convergent construct validation between the frailty diagnosis and the gross MMSE score (ranging between zero and 30). Although that result is included here for the sake of simple verification and corroboration, the most appropriate validation analysis in this case is the known-groups strategty, as presented earlier, since the assessment of the MMSE diagnosis depends on the elderly patients' education level.

For construct validation of the original scale, the authors ${ }^{(3)}$ used Pearson's correlation coefficient when comparing the EFS with the MMSE and the Barthel index. The correlation with the Barthel index was statistically significant $(r=-0.58$, $p=0.006, n=21)$, while the correlation with the MMSE was not $(r=-0.05, p=0.801, n=30)$. In this research, the Barthel index was not used because this instrument has not been validated in Brazil yet. The FIM was chosen, as this measure has already been validated and, like the Barthel index, can verify the elderly people's functional independence to perform their activities.

\section{REFERENCES}

1. Fried LP, Ferrucci L, Darer J, Williamson JD, Anderson G. Untangling the concepts of disability, Frailty and comorbidity: implications for improved targeting and a care. J Gerontol Med Sci 2004 March; 59(3):255-63.

2. Rockwood K, Hogan D, Macknigth C. Conceptualisation and measurement of frailty in elderly people. Drug Aging 2000; 17:295-302.

3. Rolfson DB, Majumdar SR, Tsuyuki RT, Tahir A, Rockwood K. Validity and reliability of the Edmonton Frail Scale. Age Ageing 2006 June; 35:526-9.

4. Hardy SE, Dubin JA, Holford TR, Gill TM. Transitions between states of disability and independence among older persons. Am J Epidemiol 2005 March;161(6):575-84.

5. Bergman $H$, Béland $F$, Karunananthan $S$, Hummel $S$, Hogan $D$, Wolfson C. Développement d'un cadre de travail pour comprendre et étudier la fragilité. Geront Soc 2004 June; 109:15-29.

6. Guillemin F, Bombardier C, Beaton DE. Cross-cultural adaptation of health-related quality of life measures: literature
According to the criterion validity results, the test showed high sensitivity but low specificity and managed to identify elderly with a cognitive deficit according to the MMSE. However, more specific research on the clock test is suggested, considering not its sensitivity but its use in the Brazilian culture. This test demands minimal knowledge of numbers. Low education levels in the elderly population, frequent in Brazil ${ }^{(17)}$, and the fact that many of them did not know the numbers made it difficult for many elderly participants to draw the watch. Therefore, in the Brazilian elderly population, low performance on the clock test may be related to difficulties that do not depend on cognitive deficit.

\section{CONCLUSIONS}

After concluding the cultural adaptation process of the Edmonton Frail Scale (EFS), the Portuguese version was applied to 137 elderly living in the community, in an interior city in São Paulo State. The obtained results confirm the content, construct and criterion validity of the adapted instrument.

The availability of a valid and reliable instrument to assess Brazilian elderly people's frailty is highly useful for health professionals, in research and in clinical practice. However, the adapted version of the EFS should also be tested in other elderly groups from other Brazilian regions.

review and proposed guidelines. J Clin Epidemiol 1993 December; 46(12):1417-32.

7. Ferrer M, Alonso J, Prieto L, Plaza V, Monso E, Marrades $R$, et al. Validity and reliability of the St George's Respiratory Questionnaire alter adaptation to a different language and culture: the Spanish example. Eur Respir J 1996; 9(6):1160-6.

8. Echevarría-Guanilo ME, Rossi LA, Dantas RAS, Santos CB dos. Cross-cultural adaptation of the Burns Specific Pain Anxiety Scale - BSPAS to be used with brazilian burned patients. Rev Latino-am Enfermagem 2006 Julho-Agosto; 14(4):526-33.

9. Dantas RAS. Adaptação cultural e validação do Questionário de Senso de coerência de Antonovsky em uma amostra de pacientes cardíacos brasileiros [tese]. Ribeirão Preto (SP): Escola de Enfermagem de Ribeirão Preto, Universidade de São Paulo; 2007.

10. Ferreira E, Dantas RAS, Rossi LA, Ciol MA. The cultural adaptation and validation of the "Burn Specific Health Scale Revised" (BSHS-R): version for Brazilian burn vitims. Burns 2008;34:994-1001. 
11. Munro BH. Statistical methods for health care research. 5.ed. Philadelphia: Lippincott; 2001.

12. Strawbridge WJ, Shema SJ, Balfour JL, Higby HR, Kaplan GA. Antecedents of frailty over three decades in an older cohort. J Gerontol B Psychol Sci 1998 January;53(1):S9-16.

13. Fried LP, Tangen CM, Walston J, Newman AB, Hirsch $C$, Mcbrunie $M A$, et al. Frailty in older adults: evidence for a phenotype. J Gerontol Med Sci 2001 Mar; 56(3):M146-M56. 14. Berg WP, Alessio HM, Mills EM, Tong C. Circunstances and consequences of falls in independent community dwelling older adults. Age Ageing 1997;26(6):261-8.
15. Dyer CAE, Watkins CL, Gould C, Rowe J. Risk-factor assessment for falls: from a written checklist to the penless clinic. Age and Aging 1998;27:569-72.

16. Speechley $M$, Tinetti $M$. Falls and injuries in frail and vigorous community elderly persons. J Am Geriatr Soc 1991 January;39(1):46-52.

17. Camarano AA. Envelhecimento da população brasileira: uma contribuição demográfica. In: Freitas EV, Py $L$, Néri $A L$, Cançado FAX, Gorzoni ML, Rocha SM. Tratado de Geriatria e Gerontologia. Rio de Janeiro: Guanabara Koogan; 2002. p. 58-71. 